\title{
CIRCULATION AND SALT INTRUSION IN THE PIAÇAGUERA CHANNEL, SANTOS (SP)
}

\author{
Luiz Bruner de Miranda ${ }^{1 *}$, Eugenio Dalle Olle, Alessandro Luvizon Bérgamo ${ }^{2}$, \\ Lourval dos Santos Silva ${ }^{3}$ and Fernando Pinheiro Andutta ${ }^{4}$ \\ ${ }^{1}$ Instituto Oceanográfico da Universidade de São Paulo \\ (Praça do Oceanográfico, 191 05508-120 São Paulo, SP, Brasil) \\ ${ }^{2}$ Universidade Federal do Pará \\ (Rua Augusto Corrêa, 01, 66075-110 Belém, PA, Brasil) \\ ${ }^{3}$ Faculdade de Tecnologia "Rubens Lara" \\ (Av. Bartolomeu de Gusmão, 110, 11045-908 Santos, SP, Brasil)
}

${ }^{4}$ School of Engineering and Physical Sciences, James Cook University (Townsville QLD 4811, Australia)

*Corresponding author: bruner@usp.br

\begin{abstract}
A B S T R A C T
Analysis of thermohaline properties and currents sampled at an anchor station in the Piaçaguera Channel (Santos Estuary) in the austral winter was made in terms of tidal (neap and spring tidal cycles) and non-tidal conditions, with the objective to characterize the stratification, circulation and salt transport due to the fortnightly tidal modulation. Classical methods of observational data analysis of hourly and nearly synoptic observations and analytical simulations of nearly steady-state salinity and longitudinal velocity profiles were used. During the neap tidal cycle the flood $(v<0)$ and ebb $(v>0)$ velocities varied in the range of $-0.20 \mathrm{~m} / \mathrm{s}$ to $0.30 \mathrm{~m} / \mathrm{s}$ associated with a small salinity variation from surface to bottom $(26.4$ psu to $30.7 \mathrm{psu}$ ). In the spring tidal cycle the velocities increased and varied in the range of $-0.40 \mathrm{~m} / \mathrm{s}$ to $0.45 \mathrm{~m} / \mathrm{s}$, but the salinity stratification remained almost unaltered. The steady-state salinity and velocity profiles simulated with an analytical model presented good agreement (Skill near 1.0), in comparison with the observational profiles. During the transitional fortnightly tidal modulation period there was no changes in the channel classification (type $2 \mathrm{a}$ - partially mixed and weakly stratified), because the potential energy rate was to low to enhance the halocline erosion. These results, associated with the high water column vertical stability $(\mathrm{RiL}>20)$ and the low estuarine Richardson number $(\mathrm{RiE}=1.6)$, lead to the conclusions: i) the driving mechanism for the estuary circulation and mixing was mainly balanced by the fresh water discharge and the tidal forcing associated with the baroclinic component of the gradient pressure force; ii) there was no changes in the thermohaline and circulation characteristics due to the forthnigtly tidal modulation; and iii) the nearly steady-state of the vertical salinity and velocity profiles were well simulated with a theoretical classical analytical model.
\end{abstract}

\section{RESUMO}

A análise de dados termohalinos e correntes medidos em uma estação fixa no Canal de Piaçaguera (Estuário de Santos) no inverno foi feita em termos de condições cíclicas da maré (quadratura e sizígia) e quase-estacionária, com o objetivo de caracterizar a estratificação da massa de água estuarina, sua circulação e transporte de sal forçados pela modulação quinzenal da maré. Foram utilizados métodos clássicos de análise de dados observacionais horários e quase sinóticos e de simulações analíticas de perfis estacionários de salinidade e do componente longitudinal da velocidade. Durante o ciclo de maré de quadratura as velocidades de enchente $(\mathrm{v}<0)$ e vazante $(\mathrm{v}>0)$ variaram de $-0.20 \mathrm{~m} / \mathrm{s} \mathrm{a} 0.30 \mathrm{~m} / \mathrm{s}$, associadas à pequena variação de salinidade entre a superfície e o fundo (26.4 psu a 30.7 psu). No ciclo de sizígia a velocidade aumentou de $-0.40 \mathrm{~m} / \mathrm{s}$ a $0.45 \mathrm{~m} / \mathrm{s}$, mas a estratificação de salinidade permaneceu praticamente a mesma. Os perfis estacionários teóricos de salinidade e de velocidade apresentaram boa concordância (Skill próximo a 1,0) quando comparados aos perfis observacionais. Durante a modulação quinzenal da maré não houve alteração na classificação do canal estuarino (tipo 2a-parcialmente misturado e fracamente estratificado), pois a taxa de aumento da energia potencial não foi suficiente para ocasionar a erosão da haloclina. Esses resultados, associados à alta estabilidade vertical $(\mathrm{RiL}>20)$ e ao número de Richardson estuarino $(1,6)$, permitem as seguintes conclusões: i) o mecanismo que forçou a circulação e os processos de mistura foi principalmente o balanço da descarga fluvial com a maré, associado ao componente baroclínico da força de gradiente de pressão; ii) não houve variações nas principais características termohalinas e da circulação devido à modulação quinzenal da maré; e iii) os perfis quase estacionários de salinidade e da velocidade foram adequadamente simulados com um modelo analítico clássico.

Descriptors: Thermohaline properties, Circulation, Theoretical-observational profiles, Salt transport, Stratification. Descritores: Propriedades termohalinas, Circulação, Perfis teóricos-observacionais, Transporte de sal, Estratificação. 


\section{INTRODUCTION}

Since earlier times maritime countries used the estuarine environments to enhance urban communities and industrial development. The Santos estuary is an outstanding Brazilian example; it is bordered by the cities of Santos, São Vicente, Guarujá, Bertioga and Cubatão which is one the most industrialized of South America.

The Piaçaguera Channel is located in the upper reaches of the Santos estuary (SE) and its northern region is oriented in the $\mathrm{N}-\mathrm{S}$ direction, and at this end industrial plantations have maritime terminals facilities (Fig. 1). In view of preceding studies in the Santos estuary, a need to broaden the knowledge of this channel emerged.

The hydrodynamics and mixing processes of the SE play a key role in the transport of properties concentration, pollutants and in the erosion, transport and deposition of river sediments. These processes are driven mainly by the estuarine circulation. However, due to water-bottom interactions there is a constant feedback between the hydrodynamic, mixing processes, estuarine substrate and morphology, at both the micro and macro-scale levels. It is a complex estuarine channel whose geometry and river discharge has been drastically altered during the last century by urban and industry development, land reclamation, dredging and effluent receptor from several industries.
In this paper the knowledge of the estuarine hydrodynamics related with the non-tidal and tidal longitudinal circulation, stratification and mixing characteristics will be applied. Further, with the steady-state analytical solutions of the longitudinal velocity and salinity profiles and the Stratificationcirculation diagram (HANSEN; RATTRAY, 1965, 1966), it will be possible to estimate numerical values of the kinematic eddy viscosity and diffusion coefficients and the relative proportion of the advection and diffusion processes to the upward salt transport.

The objective of the study covered in this article is the analysis of specific series of observational data on the thermohaline properties and velocity to improve the knowledge on the dynamics at the upper reaches of this channel, during a winter fortnightly tidal modulation. In order to achieve such goal the study aims specifically at: i) characteristics on the tidal and non-tidal thermohaline properties, currents, stability of the water column and changes in the potential energy anomaly ii) channel classification; iii) advective salt transport and: iv) analytical simulation of velocity and salinity steady-state profiles, enabling to estimate some of its free parameters (kinematic viscosity and diffusion coefficients).

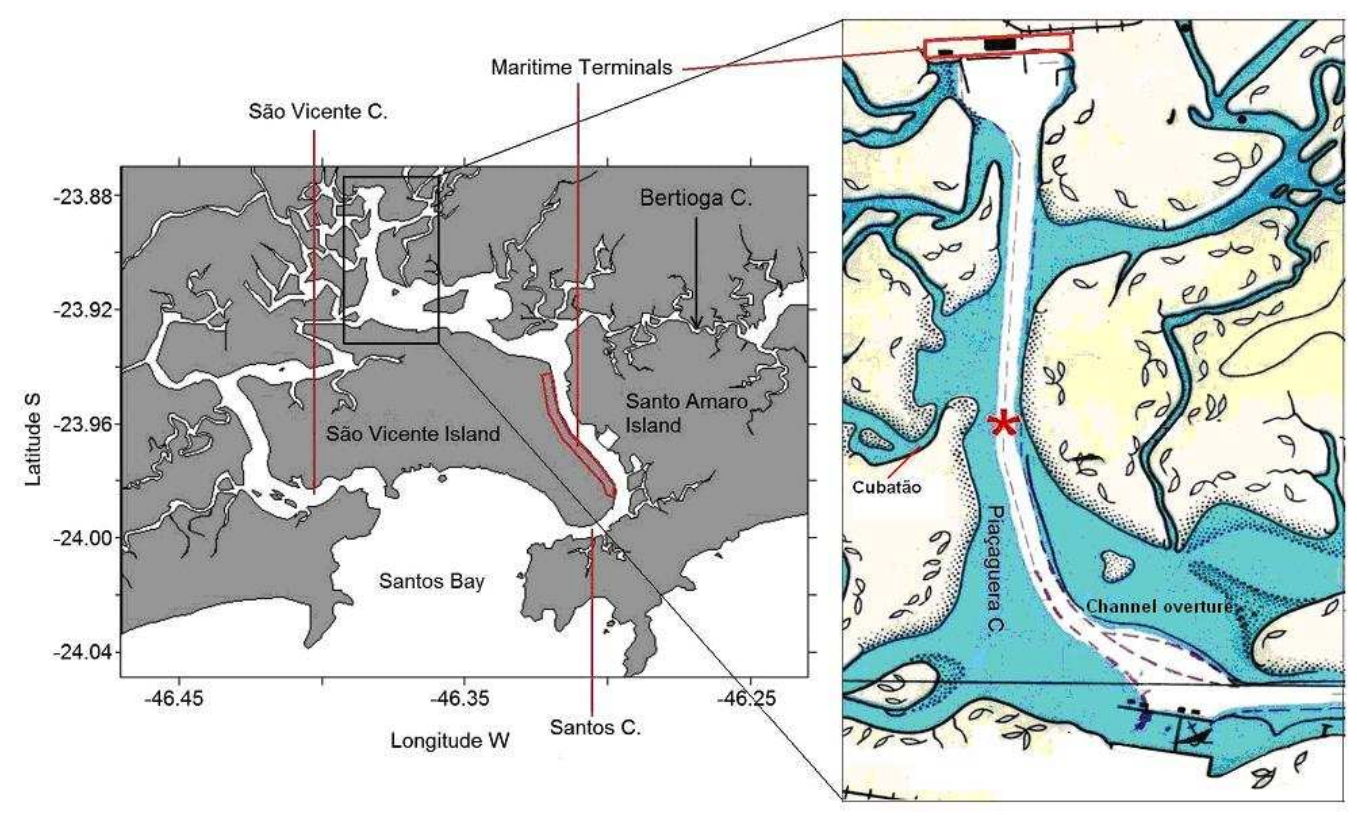

Fig. 1. The Santos Estuarine System. The São Vicente (center) and Santo Amaro (east) islands, the estuarine channels (Santos, São Vicente, Piaçaguera and Bertioga) and Santos Bay south of the São Vicente Island. The Piaçaguera Channel and the anchor station $(*)$ shown in the Nautical Chart DHN 1701 (right). 
Finally, it is worth to mentioning that channels water column and bottom sediments have a high contamination level (CETESB, 1981, 2001). Hence, according to earlier investigations (OFFICER, 1977; HAMILTON; WILSON, 1980), the knowledge of estuarine circulation, transport processes and mixing are essential to the actions necessary to investigate the biological and chemical aspects of water quality, sediment erosion, transport and sedimentation as a tool for pollutant control.

\section{Study Area}

In 1950's and 1960's pioneering work on the measurements of hydrographic properties, currents and solids in suspension was made by the Hydraulic Laboratory of the Polytechnic School of Engineering of the University of São Paulo (SP) reported in CTH (1959, 1966). In the 1970's measurements were carried out by consulting companies. The stratification and salt balance was used to classify the main channel of the system and to estimate the flushing time which varied from 2.1 to 5.0 days (CETESB, 1977). At the end of this decade measurements were made with the technical collaboration of the Instituto Oceanográfico da Universidade de São Paulo (IOUSP) and the Superintendência de Saneamento Básico do Estado de São Paulo (SABESP), with the objective to obtain complementary data for the outfall submarine project planned for the Santos Bay (Fig. 1). Studies focusing on sediments, ecological and chemical aspects of the Santos estuary were published by Fúlfaro and Ponçano (1976). Heavy metal concentration in the Santos Bay was initially investigated in 1983 (FÚLFARO et al., 1983) and further by Figueira et al. (2004). Updated depositional history studies and isotopic composition of the organic matter in the SE and the Santos Bay may be found in recent publications.

A pioneering study on the numerical modeling of the SE and the inner continental shelf forced by the main tidal components was published by Harari and Camargo (1998). Although taking into account only barotropic conditions it is possible to find out in this work some interesting features: stronger ebbing circulation east side of the bay and convergent circulation due to flooding currents in the channels of São Vicente and Bertioga; this work was further improved by Harari et al. (2001) and Harari et al. (2002) with the theoretical simulations of the barotropic circulation in the Piaçaguera Channel validated with observational results. A description of theoretical and applied studies related to the numerical modeling of the effluent dispersion using the SE as the region to be investigated was presented by Diniz and Meyer (2004).

Variations on tidal and non-tidal circulation, thermohaline characteristics, salt transport, classification and tidal effects on the nutrients, phytoplankton concentration, suspended matter and chlorophyll-a, due to the tidal modulation during consecutive neap-spring tidal cycles in the SE channels (São Vicente, Santos and Bertioga) were investigated by Miranda et al. (1998), Gianesella et al. (2000), Bernardes and Miranda (2001) and Moser et al. (2005).

\section{Data SAmpling And Methodology}

Time series of hourly profiles of hydrographic properties (S,T,p) and current velocity (speed and direction) were recorded at an anchor station in the Piaçaguera Channel (Station: lat. $23^{\circ} 53,987^{\prime}$ S; long. $046^{\circ} 22,640^{\prime} \mathrm{W}$ ), at a depth closely to $11 \mathrm{~m}$ (Fig. 1). This station is located south of the maritime terminals and near the Cubatão River outflow (Fig. 1). According to the field experiment report the oceanographic sampling was made with a CTD/Current meter Falmouth, model 2D-ACM. The station was monitored during 19 days $(460 \mathrm{~h})$, from June 23 to July 11, 2001, covering 36 semidiurnal tidal cycles. However, due to weather conditions, maritime traffic and equipment failure the time series presented discontinuities which ranged from one hour up to several hours. Despite such discontinuities time series of salinity, density and longitudinal velocity component were analysed. From this time series a set of Eulerian hourly profiles of hydrographic properties and velocity of three complete semidiurnal tidal cycles (37 hours), for the neap (June 28-29, 2001) and spring (July 04-06, 2001), were used to compute the non-tidal nearly steady-state salinity and the v-velocity component profiles.

The temperature $\left(\mathrm{T}\right.$ in ${ }^{\circ} \mathrm{C}$ ) and salinity $(\mathrm{S}$ in psu) profiles were analysed taking into account its tidal and non-tidal characteristics. The density was calculated with the International Equation of State of Sea Water. The velocity vector was decomposed in longitudinal (N-S or v-component) and secondary (E$\mathrm{W}$ or u-component) components according to the local referential system Oxyz (Ox, Oy and $\mathrm{Oz}$ with the origin on the free surface and oriented positively toward East, South and upward, respectively); ebbing and flooding currents are indicated by $\mathrm{v}>0$ and $\mathrm{v}<0$, respectively. All raw data were submitted to quality control and then interpolated in terms of the nondimensional depth $(\mathrm{Z}=\mathrm{z} /|\mathrm{h}(\mathrm{t})|)$ at intervals -0.1 from the surface $(Z=0)$ down to the bottom $(Z=-1.0)$ and at hourly time intervals.

The description of the steady-state dynamic response and salt stratification due to the combination of the river discharge, density-driven forcing and wind was approximated by the two-dimensional Hansen and Rattray (1965) steady-state analitical solution, further extended by Officer (1976, 1977), Prandle (1985, 
2004) and others, to include bottom frictional effects. The Hansen and Rattray's classical model consider the balance of the barotropic and baroclinic modes, with wind stress forcing on the surface and no-slip at the bottom as upper and lower boundary conditions, respectively. An idealized rectilinear coastal-plain estuary ( $\mathrm{B}$ and $\mathrm{h}$ being the width and depth, respectively) and laterally homogeneous is assumed in the model. Bottom friction due to the tidal currents is the predominant cause of turbulent mixing but have no other influence upon the net circulation on the estuary.

The central regime solutions, satisfying boundary conditions and assuming constant kinematic eddy viscosity and diffusion coefficients, for steadystate v-velocity $\left(\mathrm{v}_{\mathrm{c}}\right)$ and salinity $\left(\mathrm{S}_{\mathrm{c}}\right)$ profiles in terms of the non-dimensional depth $(\mathrm{Z})$, take the following forms obtained from the derivation and integration of the current function (HANSEN; RATTRAY ,1965);

$$
\begin{aligned}
& \mathrm{v}_{\mathrm{c}}(\mathrm{y}, \mathrm{Z})=\left(\frac{v}{48}\right) \frac{\mathrm{gh}^{3} \frac{\partial \rho}{\partial \mathrm{y}}}{\rho \mathrm{N}_{\mathrm{z}}}\left(1-9 \mathrm{Z}^{2}-8 \mathrm{Z}^{3}\right)-\left(\frac{3}{2}\right) \mathrm{v}_{\mathrm{f}}\left(-1+\mathrm{Z}^{2}\right) \\
& +\frac{1}{4} \frac{\tau_{\mathrm{w}} \mathrm{h}}{\rho \mathrm{N}_{\mathrm{z}}}\left(1+4 \mathrm{Z}+3 \mathrm{Z}^{2}\right),
\end{aligned}
$$

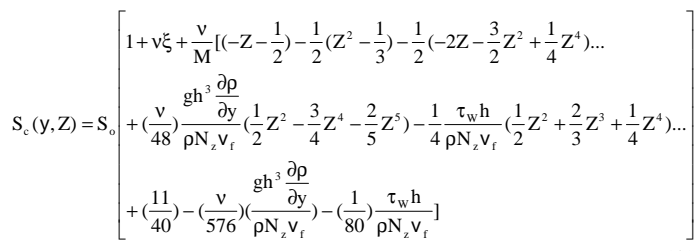

The v-component profile of the velocity $\mathrm{v}_{\mathrm{c}}=\mathrm{v}_{\mathrm{c}}(\mathrm{y}, \mathrm{Z})$ (eq. 1) is expressed as the sum of three circulation modes: i) the gravitational circulation in which the pressure gradient due to the longitudinal salinity (density) gradient (temporally and vertically constant) is balanced by frictional forces, which is associated with an analog of the Rayleigh number $\left(R_{a}\right)$ times the $v$ parameter defined as the ratio of the tidal diffusion term to the total upstream net salt transport due to the advection and tidal diffusion (SIMPSON et al., 2001); ii) the velocity generated by the river discharge $\left(\mathrm{v}_{\mathrm{f}}=\mathrm{Q}_{\mathrm{f}} / \mathrm{Bh}\right)$; and iii) the contribution of the surface wind-stress forcing, $\mathrm{t}_{\mathrm{W}}$. The quantity $\mathrm{N}_{\mathrm{z}}$ is the vertical kinematic coefficient of eddy viscosity treated as a constant. In the theory the density $\rho$ is approximated by the linear equation of state of sea water. It should be pointed out that the analytical expression of the equation (1), is equivalent to the one derived latter by Officer (1976).

In the salinity profile $S_{c}=S_{c}(y, Z)$ (eq. 2) the quantity $S_{o}$ is the time-mean salinity averaged along the water depth. The quantities $\xi$ and $\mathrm{M}$ are the dimensionless longitudinal coordinate and the ratio of the tidal mixing to the river flow given by $\xi=\mathrm{v}_{\mathrm{f}} \mathrm{y} / \mathrm{K}_{\mathrm{ho}}$ and $\mathrm{M}=\mathrm{K}_{\mathrm{z}} \mathrm{K}_{\mathrm{ho}} /\left(\mathrm{v}_{\mathrm{f}} \mathrm{h}\right)^{2}$, where $\mathrm{K}_{\mathrm{z}}$ and $\mathrm{K}_{\mathrm{ho}}$ are the vertical and horizontal kinematic coefficient of eddy salt diffusion considered as constants, respectively. Taking into account the hypothesis of the Hansen and Rattray's theory the eddy coefficients $\left(\mathrm{N}_{\mathrm{z}}, \mathrm{K}_{\mathrm{z}}\right.$ and $\left.\mathrm{K}_{\mathrm{ho}}\right)$ and the wind stress $\left(\tau_{\mathrm{W}}\right)$ will be treated as free parameters, to be used to validate the theoretical profiles against near-steady state profiles derived from experimental data. In order to quantify the agreement between the theoretical results of the velocity and salinity profiles and the in situ data, the method suggested by Wilmott (1981) based in the Skill parameter defined by Warner et al. (2005) was used,

$$
\text { Skill }=1-\frac{\Sigma\left|X_{\text {model } l}-X_{o b s}\right|^{2}}{\Sigma\left(\left|X_{\text {mod } e l}-\left(X_{m}\right)_{o b s}\right|+\left|X_{o b s}-\left(X_{m}\right)_{o b s}\right|\right.}
$$

The quantities $\mathrm{X}_{\mathrm{obs}}$ and $\mathrm{X}_{\text {model }}$ are the observational properties (v-velocity component or salinity) and the corresponding values calculated by the model $\left(\mathrm{v}_{\mathrm{c}}\right.$ and $\left.\mathrm{S}_{\mathrm{c}}\right)$ and $\left(\mathrm{X}_{\mathrm{m}}\right)_{\text {obs }}$ its depth mean observational values. According to the equation (3) the Skill parameter varies from 1 to zero indicating the best fit and a complete disagreement between observation and the theoretical result, respectively. The validation skill parameter as defined (eq. 3) was used to evaluated numerical simulations of the Curimataú River estuary (RN-Brasil) with a three dimensional model (Delft 3D- Flow) in comparison with set of time series measurements (ANDUTTA et al., 2006).

The classical Stratification-circulation diagram theoretically derived by (HANSEN; RATTRAY, 1966) was used in the estuary classification and to calculate the relative contribution of the advective and diffusion processes to the upestuary salt transport through its key parameter $(v)$. The nearly-steady salinity $[S=S(x, z)=S(x, Z)]$ and the longitudinal velocity component $[\mathrm{v}=\mathrm{v}(\mathrm{x}, \mathrm{Z})=\mathrm{v}(\mathrm{x}, \mathrm{Z})]$ used to calculate the stratification $\left(\mathrm{p}_{\mathrm{e}}\right)$ circulation parameters $\left(p_{c}\right)$ were obtained from the hourly timemean values of vertical profiles based on the algorithms of Miranda et al. (2002) and Bérgamo et al. (2002). These parameters were also calculated from the theoretical profiles simulations of the v-velocity component and salinity. Taking into account the residual values of velocity and salinity the advective salt transport was calculated with the assumption that the channel was laterally homogeneous. 
Stability characteristics during the tidal cycle and the main forcing mechanisms for the circulation and mixing processes were analyzed by the classical Richardson layer and estuarine numbers, $\mathrm{Ri}_{\mathrm{L}}$ and $\mathrm{Ri}_{\mathrm{E}}$, respectively (FISCHER, 1976; BOWDEN, 1978):

$$
R i_{L}(t)=\frac{g h(t) \Delta \rho_{V}(t)}{\rho_{m}(t)\left(\mathbf{v}_{\mathbf{m}}\right)^{2}(t)} \text { and } R i_{E}=\frac{g \Delta \rho_{H} \mathbf{h}_{\mathbf{m}} \mathbf{v}_{f}}{\rho_{m}\left(\mathbf{v}_{r m q}\right)^{3}} \approx \frac{g \Delta \rho_{H} \mathbf{h}_{\mathbf{m}} \mathbf{v}_{a}}{\rho_{m}\left(\mathbf{v}_{r m s}\right)^{3}}
$$

in the first expression $\mathrm{g}, \mathrm{h}(\mathrm{t}), \Delta \rho_{\mathrm{v}}(\mathrm{t}), \rho_{\mathrm{m}}(\mathrm{t})$ and $\left(\mathrm{v}_{\mathrm{m}}\right)^{2}$ are the gravity acceleration, the depth, the bottom minus the surface densities, the mean-depth density, and the square of the mean-depth velocity. In the $\mathrm{Ri}_{\mathrm{E}}$ definition $\Delta \rho_{\mathrm{H}}, \mathrm{h}_{\mathrm{m}}, \mathrm{v}_{\mathrm{f}}=\mathrm{v}_{\mathrm{a}}, \rho_{\mathrm{m}}$ and $\mathrm{v}_{\mathrm{rms}}$, are the differences of the densities at the mouth and the estuary head, $\mathrm{v}_{\mathrm{a}}$ is the residual velocity and $\left(\mathrm{v}_{\mathrm{rms}}\right)^{3}$ is the root mean square cubed of the $v$-velocity component which controls the intensity of tidal stirring; due to the lack of the fresh water discharges the velocity $\left(\mathrm{v}_{\mathrm{f}}\right)$ was approximate by the residual velocity $\mathrm{v}_{\mathrm{a}}$

The $\mathrm{Ri}_{\mathrm{L}}=20$ is the upper limit for which the turbulent mixing occurs near the halocline in partially mixed estuaries. Bellow this critical number $\left(\mathrm{Ri}_{\mathrm{L}}<20\right)$ the bottom turbulence became effective to the vertical mixing process in the water column. Bellow $\mathrm{Ri}_{\mathrm{L}}=2$ the turbulent mixing is isotropic fully developed and the water column is unstable and for $\mathrm{Ri}_{\mathrm{L}}>20$ the water column is stable with low vertical mixing (DYER; NEW, 1986).

The energy of the tidal Straining Process due to the Periodic Stratification (SIPS) due to the fortnightly tidal modulation and its influence on water column stability was calculated in terms with the potential energy anomaly $\phi$ (NUNES et al., 1989; SIMPSON et al. (1990)

$\phi=\frac{1}{h} \int_{-h}^{0}\left(\rho_{m}-\rho\right) g z d z ; \rho_{m}=\frac{1}{h} \int_{-h}^{0} \rho(z) d z$

where $\rho=\rho(z)$ and $\rho_{m}$ are the density profile and its mean-depth, respectively. $\phi$ is the work per volume unit required to mix of the water column $\left(\mathrm{J} / \mathrm{m}^{3}\right.$, in the SI system); $\phi=0$ for a well mixed estuary and increases for a high stratified estuary. Taking into account that for a non-compressible horizontal flow the local density variation is related to the advection term by<smiles>[Te][As]=[Te]</smiles>

and it is readily shown that the time rate of $\phi$ is given by (SIMPSON et al., op. cit.).

$$
\frac{\partial \phi}{\partial t}=\frac{g}{h} \frac{\partial \rho}{\partial y} \int_{-h}^{0}\left(\mathbf{v}-\mathbf{v}_{\mathbf{m}}\right) z d z,
$$

where $\mathrm{v}=\mathrm{v}(\mathrm{z})$ and $\mathrm{v}_{\mathrm{m}}$ are the $\mathrm{v}$-velocity component profile and its mean depth, respectively. In terms of the non-dimensional depth $(\mathrm{Z})$ this equation may be written as

$$
\frac{\partial \phi}{\partial t}=h g \frac{\partial \rho}{\partial y} \int_{-1}^{0}\left(\mathbf{v}-\mathbf{v}_{\mathbf{m}}\right) Z d Z
$$

and $\left(\frac{\partial \phi}{\partial t}\right)$ is to be expected to have low and high values for a well mixed and a highly stratified estuary, respectively. The time rate of $\phi$ will be used to compare the tidal stirring intensity changes over the fortnightly tidal modulation of the Piaçaguera Channel based on the observational results of $\mathrm{v}=\mathrm{v}(\mathrm{y}, \mathrm{z})=\mathrm{v}(\mathrm{y}, \mathrm{Z})$.

Understanding the development and breakdown of stratification is a key to shallow sea and estuarine oceanography. The stratification intensity in the water column is crucial in controlling the intensity of vertical mixing and hence the vertical fluxes of water properties such as heat, salt, momentum, and nutrient concentrations. This intensity may be of critical importance in controlling the biological production because inhibiting vertical displacement might influence the degree of light exposure experienced by marine organisms (SIMPSON et al., 1990).

\section{The Forcing Mechanisms}

\section{The Fresh Water Input}

Fresh water is discharged into the SE from a complex drainage basin with several rivers with springs in the highlands maritime border (Serra do Mar). Fresh water feeding the Piaçaguera Channel are mainly from the following rivers: Piaçaguera, Cubatão, Quilombo and Mogi. The processes of erosion and transport carry high concentration of suspended matter which are deposited in the mangrove forest and the in the estuary bed.

The complexity of this drainage basin and the lack of the gauging stations of river discharges make the calculation of fresh water input to the channel uncertain. For the whole estuary the historical data published by CETESB (1977) gives an annual mean estimate of $42.8 \mathrm{~m}^{3} / \mathrm{s}$ which is close agreement with the one based on the climatological values of air temperature, precipitation and evapotranspiration rates $\left(41.0 \mathrm{~m}^{3} / \mathrm{s}\right)$ unpublished data calculated by Dr. Mario Pereira da Silva (personal communication). For the Cubatão River there was a gauging station (3E-077 6Ponte Preta - lat. 235' $39^{\prime \prime}$; ; long. 046 $27^{\prime} 26^{\prime \prime} \mathrm{W}$ ) with only a few years of measurements which gives an annual climatological mean of $7.5 \mathrm{~m}^{3} / \mathrm{s}$. 
Tidal Characteristics

Hourly tidal heights at the station of Conceiçãozinha (lat. $23^{\circ} 58,1^{\prime} \mathrm{S}$; long. $046^{\circ} 17,5^{\prime} \mathrm{W}$ ) were used for the tidal analysis and prediction of tidal spectrum obtained according to Pawlowicz et al. (2002). These results agree very well with the previous ones (FRANCO, 2000) indicating that the estuary is microtidal (ranges less than $2 \mathrm{~m}$ ) and semidiurnal mixed (form number 0.32). Prominent peaks occur at diurnal $\left(\mathrm{K}_{1}, \mathrm{O}_{1}\right)$, semi-diurnal $\left(\mathrm{M}_{2}, \mathrm{~S}_{2}\right)$ and quarterdiurnal $\left(\mathrm{M}_{4}\right)$. Smaller peaks also appear at the $\mathrm{M}_{6}$ tidal harmonic.

Tidal oscillations from June $1^{\text {st }}$ to July 31 , 2001 corresponding in the relative time scale from $0 \mathrm{~h}$ to $1.400 \mathrm{~h}$, and the experimental period neap-spring tidal cycle is shown by the horizontal bar (Fig. 2).

During the neap tide observation period northerly winds were strong (speed up to $60 \mathrm{~km} / \mathrm{h}$ ) and almost damped the tidal oscillations and a quick decrease in the tidal oscillations of $0.6 \mathrm{~m}$ was observed (Fig. 2). By this time the measurements had to be interrupted for several hours for safety reasons. In the beginning of the subsequent spring tide it was observed a small increase in the amplitude of the tidal oscillations and the mean sea level remained low and superimposed to the tidal oscillations with amplitudes of almost $1.5 \mathrm{~m}$.

\section{EXPERIMENTAL AND THEORETICAL RESULtS}

Neap and Spring Tidal Experiments

The Eulerinan vertical salinity profiles variations $[S=S(Z, t)]$ generated by the influence of tidal diffusion, tidal currents and the river discharge in the neap-spring tidal experiments (28-29 and 04-06 of June and July, 2001, respectively) covering three semidiurnal tidal cycles are presented in Fig. 3. These profiles show the advective influence of the ebbing and flooding tidal currents, the halocline intensification and erosion due to vertical mixing intensification during the tidal cycle and smaller differences between neap and spring tidal cycles. The surface and bottom salinities (in psu) varies in the intervals: $25.6<\mathrm{S}<29.7$ and $30.2<\mathrm{S}<30.7$ (Fig. 3-A) for the neap and are slightly smaller for the spring tides $(25.9<$ S $<29.2$ and $29.5<$ S $<30.4$ ) (Fig. 3-B).

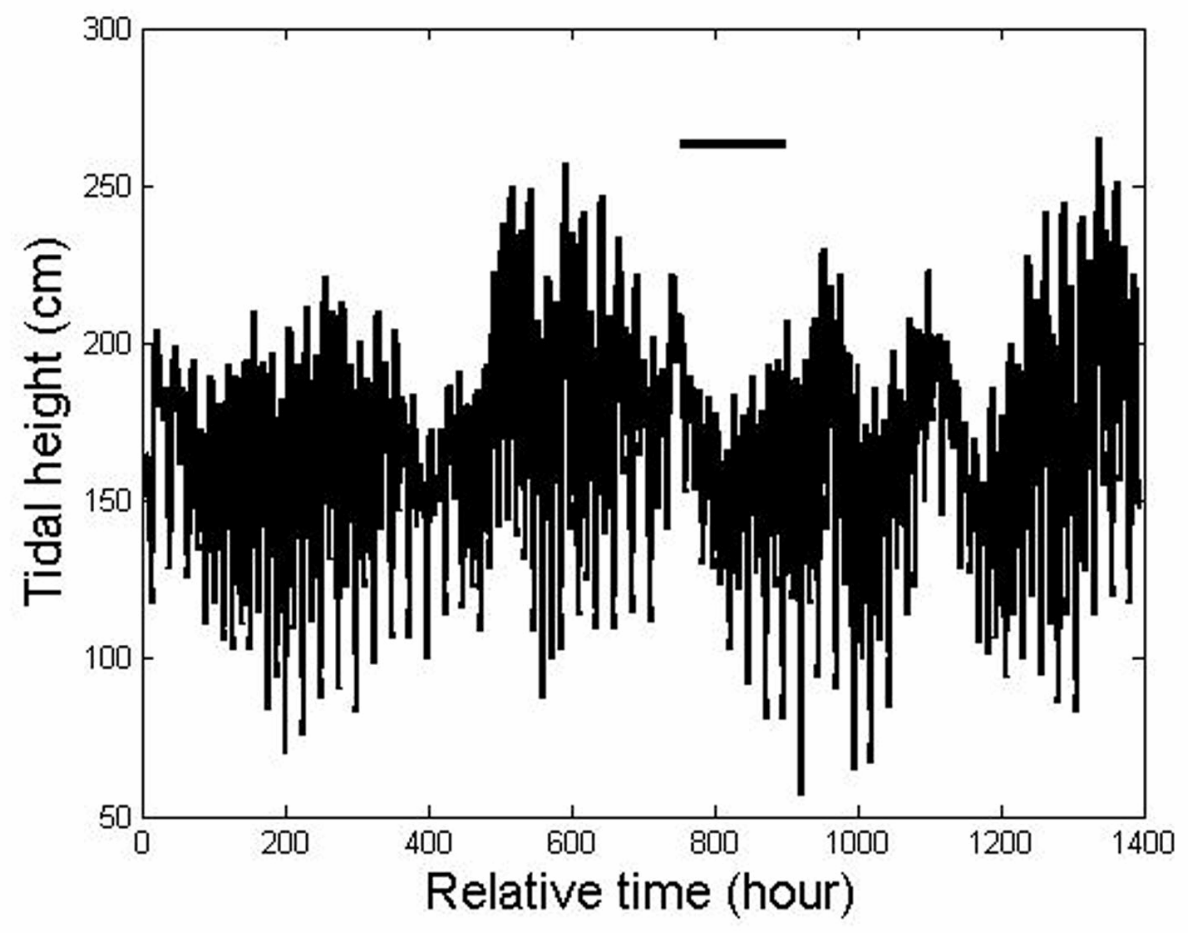

Fig. 2. Time series of hourly tidal heights from June $1^{\text {st }}$ to July 31,2001 . The measurement period, from June, 23 to July, 11 is indicated by the horizontal bar. 
(A)

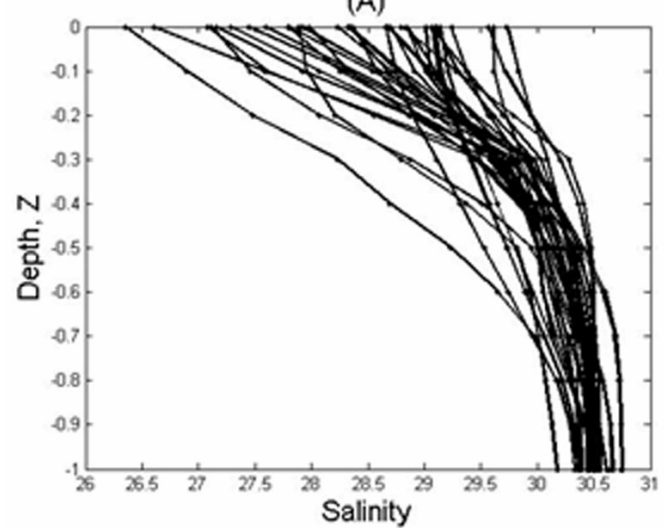

(B)

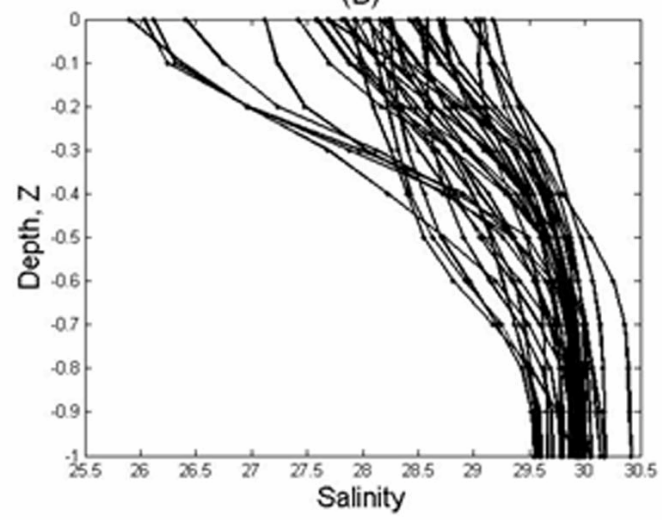

Fig. 3. Eulerian time series of salinity profiles $[S=S(Z, t)]$ at the neap (A) and spring (B) tide cycles (28-29 and 04-06 of June and July, 2001, respectively).

Due to the typically estuary small temperature variations the thermohaline characteristics of the neap-spring tidal cycles are shown by the scatter T-S Diagram (Fig. 4). The images of the T-S plots show the estuarine water mass characterized by a small temperature variation $\left(20.3^{\circ} \mathrm{C}\right.$ to $\left.22.0^{\circ} \mathrm{C}\right)$ associated with salinities ranging from $25.6 \mathrm{psu}$ to $30.7 \mathrm{psu}$. There is a distinctive T-S scatter for the neap (o) and spring ( $\mathrm{x}$ ) tidal cycles with slightly higher temperatures in the last one.

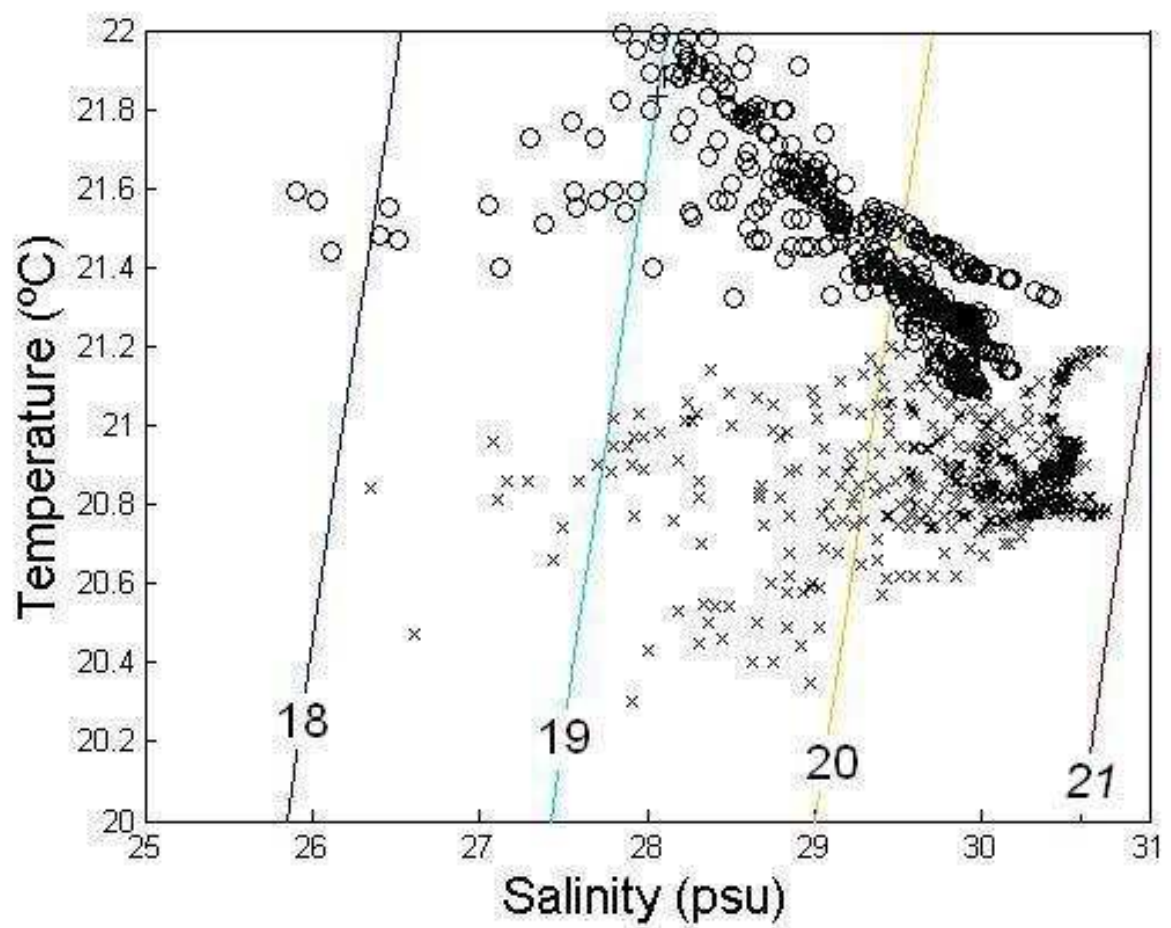

Fig. 4. Scatter T-S Diagram for the neap (o) and spring (x) tide cycles (28-29 and 04-06 of June and July, 2001, respectively). Isopicnals of the density is given in Sigma-t units. 
The time-depth mean profiles of salinity $[S=\langle S(Z)>]$ at the neap and spring tidal cycles reflect the small differences in the Eulerian profiles despite the fortnightly tidal modulation and the low vertical salinity stratification (bottom minus surface salinities equal to 2.5) with very close time-depth mean values (29.8 psu and $29.2 \mathrm{psu}$ ), respectively. These profiles will be shown later in comparison to the steady-state simulations.

The Eulerian profiles of the $v$-velocity component $[\mathrm{v}=\mathrm{v}(\mathrm{Z}, \mathrm{t})]$ associated with the salinity profiles (Fig. 3) showed distinctive patterns with asymmetric variations from $-0.18 \mathrm{~m} / \mathrm{s}$ to $0.30 \mathrm{~m} / \mathrm{s}$ (Fig. 5 -A) and $-0.39 \mathrm{~m} / \mathrm{s}$ to $0.46 \mathrm{~m} / \mathrm{s}$ (Fig. 5-B) for the neapspring tidal conditions, respectively (Fig. 5-A,B).

During the neap-spring tidal experiment there are profiles showing ebbing ( $v>0)$ and flooding $(\mathrm{v}<0)$ unidirectional motions and some exhibiting the classical bidirectional circulation with depths of nomotion which characterizes the compensating flooding currents due to the up-estuary baroclinic forcing (Fig. $5)$. The non-tidal velocity profiles indicate the twolayer estuarine circulation down $(v>0)$ and up-estuary $(\mathrm{v}<0)$ in the upper and lower layers, respectively, with no-motion depths at $\mathrm{Z}=-0.4$ and $\mathrm{Z}=-0.5$ which is the characteristic bidirectional motion of the partially mixed estuaries due to the fresh water discharge, baroclinic forcing and tidal stirring. The nearly steadystate residual current $\left(\mathrm{v}_{\mathrm{a}}\right)$ are down-estuary with speeds of $0.009 \mathrm{~m} / \mathrm{s}$ and $0.003 \mathrm{~m} / \mathrm{s}$ for the neap and spring tidal cycles, respectively. These profiles will be shown comparatively to the nearly steady-state analytical simulations.

The down $(>0)$ and up-estuary $(<0)$ salt transport intensities due to the residual velocity component and the baroclinic forcing, under the assumption that the channel is laterally homogeneous, decreased from $3.0 \mathrm{~kg} / \mathrm{s} . \mathrm{m}$ to $0.85 \mathrm{~kg} / \mathrm{s} . \mathrm{m}$ and -0.32 $\mathrm{kg} / \mathrm{s} . \mathrm{m}$ to $-0.11 \mathrm{~kg} / \mathrm{s} . \mathrm{m}$ for the neap and spring tidal cycles, respectively.

The water column stability variation and the ratio of the buoyancy input due to the fresh water discharge and the tidal stirring, during the neap and spring tidal cycle was investigate by the Richardson layer and estuarine numbers, $\mathrm{Ri}_{\mathrm{L}}$, and $\mathrm{Ri}_{\mathrm{E}}$ (eq. 4). In the neap and spring tidal cycles the water column tends to be stable $\left(\mathrm{Ri}_{\mathrm{L}}>20\right.$, but there was some values with $\mathrm{Ri}_{\mathrm{L}}$ close or lower than 20 , which indicated a possible occurrence of turbulent mixing across the halocline. For spring tidal cycle the calculated Richardson Estuarine number is 1.6 and the fresh water discharge and tidal currents are the main forcing mechanisms.

Time variations of the longitudinal velocity component $(\mathrm{v})$ during the neap and spring tidal conditions on the surface $(\mathrm{Z}=0.0)$, middle depth $(\mathrm{Z}=-$ $0.5)$ and near the bottom $(Z=-0.9)$ are shown in Fig. 6. At $Z=0.0$ and in the neap tide, the time variation of the current has an asymmetric behavior of the flooding $(\mathrm{v}<0)$ and ebbing $(\mathrm{v}>0)$ currents (with speeds from $0.06 \mathrm{~m} / \mathrm{s}$ to $0.27 \mathrm{~m} / \mathrm{s}$ ) not well correlated with the time variations in deeper layers, and at the end of the sampling period the circulation in this layer was towards north $(\mathrm{v}<0)$ in opposition with the near surface circulation (Fig. 6A). However, the currents at the spring tide are in phase at all depths and well correlated with the tidal oscillation and we may observe an increase in the velocity shear towards the bottom (Fig. 6-B).
(A)

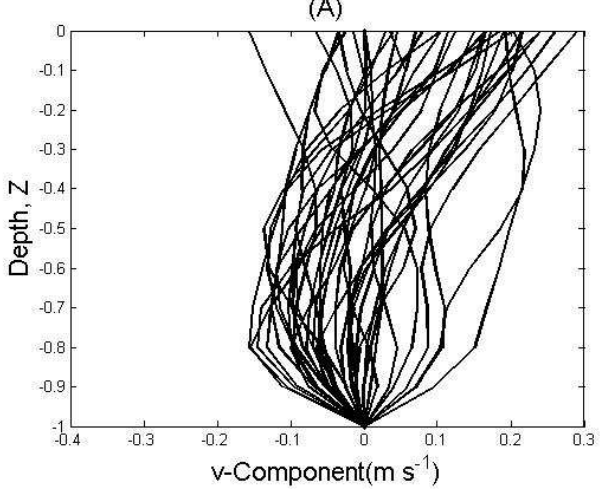

(B)

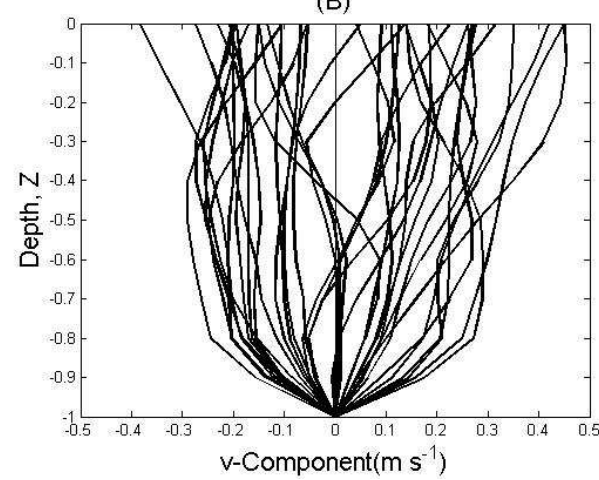

Fig. 5. Eulerian time series of $\mathrm{v}$-velocity profiles $[\mathrm{v}=\mathrm{v}(\mathrm{Z}, \mathrm{t})]$ at the neap (A) and spring (B) tide cycles (28-29 and 04-06 of June and July, 2001, respectively). 
(A)

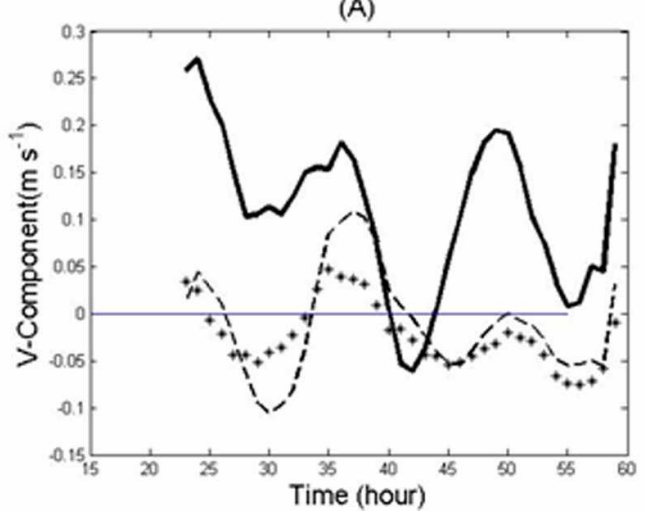

(B)

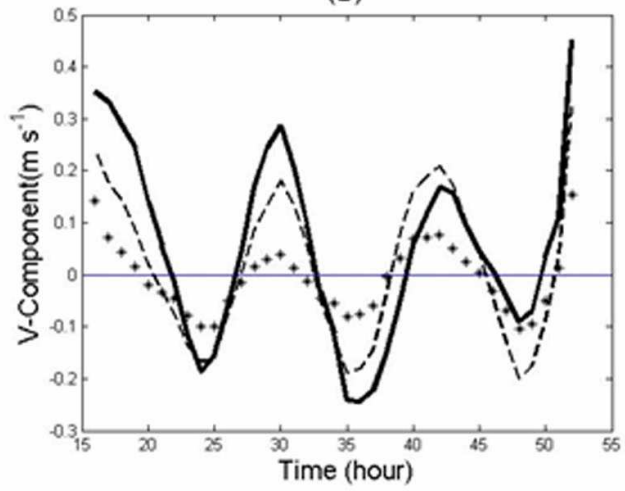

Fig. 6. Time variation of the v-velocity component at the surface $(\mathrm{Z}=0$ - solid line), middle depth $(\mathrm{Z}=-0.5$-- dashed line $)$ and near bottom ( $Z=-0.9$ - stars) for neap (A) and spring (B) tidal conditions (28-29 and 04-06 of June-July, 2001, respectively).

The current roses (not shown) were draw for the neap and spring tidal cycles and its analysis for the depths $\mathrm{Z}=0.0, \mathrm{Z}=-0.5$ and $\mathrm{Z}=-0.9$ indicated that the secondary currents (u-velocity component) were almost absent in the surface layer and presented a small increase up to $0,01 \mathrm{~m} / \mathrm{s}$ towards the bottom.

\section{Steady-state Analytical Simulations}

In the Hansen and Rattray's analytical steady-state solutions of the v-velocity component $\left(\mathrm{v}_{\mathrm{c}}\right)$ and salinity $\left(\mathrm{S}_{\mathrm{c}}\right)$ (eqs. 1 and 2), in addition to the free parameters $\left(\mathrm{N}_{\mathrm{z}}, \mathrm{K}_{\mathrm{z}}, \mathrm{K}_{\mathrm{ho}}\right.$ and $\left.\tau_{\mathrm{W}}\right)$, we took into account the following physical quantities obtained from the experimental results: i) the mean time-depth or residual velocity $\left(\mathrm{v}_{\mathrm{a}}\right)$, replacing the velocity driven by the river discharge $\mathrm{v}_{\mathrm{f}}$; ii) the mean water depth (h); iii) the $v$ parameter, obtained from the Stratificationcirculation Diagram (results presented in item bellow), and; iv) the distance of the anchor station from the mouth $(\mathrm{x})$ measured on the nautical chart. The remaining parameters: the time-depth mean salinity $S_{a}$ and the longitudinal density gradient were adjusted to obtain the best theoretical versus observational profiles fit as indicate by the Skill parameter (eq. 3). All numeric values used in the theoretical simulation are presented in Table 1 and we can notice that in the spring tide simulations the kinematics eddy coefficients $\mathrm{N}_{\mathrm{z}}\left(\mathrm{K}_{\mathrm{z}}\right)$ are two times higher (ten times lower) than the one for the neap tide simulations, however, for the horizontal eddy diffusion coefficient $\mathrm{K}_{\mathrm{ho}}$ its numerical values were the same for both tidal cycles.

The best fits of the theoretical v-velocity component $\left(\mathrm{v}_{\mathrm{c}}\right)$ and salinity profiles $\left(\mathrm{S}_{\mathrm{c}}\right)$ in comparison with the corresponding observational profiles are shown in Figures 7 and 8 for neap and spring tidal cycles, respectively.
Table 1. Estimated free parameters and the ones obtained from the experimental results $(*)$ used to the theoretical simulation of the steady-state profiles of the v-velocity component $\left(\mathrm{v}_{\mathrm{c}}\right)$ and salinity $\left(\mathrm{S}_{\mathrm{c}}\right)$, for the neap-spring tidal cycles conditions.

\begin{tabular}{lll}
\hline \hline Variables & Neap tide & Spring tide \\
\hline$*_{\mathrm{v}_{\mathrm{f}} \mathrm{V}_{\mathrm{a}}}$ & $0.009 \mathrm{~m} / \mathrm{s}$ & $0.003 \mathrm{~m} / \mathrm{s}$ \\
$*_{\mathrm{h}}$ & $11.0 \mathrm{~m}$ & $11.0 \mathrm{~m}$ \\
$*_{\mathrm{n}}$ & 0.85 & 0.85 \\
S $_{\mathrm{o}}$ & 26.5 & 27.9 \\
${ }^{\mathrm{S}_{\text {mouth }}}$ & 33.0 & 33.0 \\
S $_{\text {head }}$ & 1.0 & 1.0 \\
$*_{\Delta \mathrm{x}}$ & $20000 \mathrm{~m}$ & $20000 \mathrm{~m}$ \\
$*_{\mathrm{x}}$ & $17000 \mathrm{~m}$ & $17000 \mathrm{~m}$ \\
$\mathrm{~N}_{\mathrm{z}}$ & $4 \times 10^{-3} \mathrm{~m}^{2} / \mathrm{s}$ & $9 \times 10^{-3} \mathrm{~m}^{2} / \mathrm{s}$ \\
$\mathrm{K}_{\mathrm{z}}$ & $1.5 \times 10^{-4} \mathrm{~m}^{2} / \mathrm{s}$ & $2.5 \times 10^{-5} \mathrm{~m}^{2} / \mathrm{s}$ \\
$\mathrm{K}_{\mathrm{ho}}$ & $1.0 \times 10^{3} \mathrm{~m}^{2} / \mathrm{s}$ & $1.0 \times 10^{3} \mathrm{~m}^{2} / \mathrm{s}$ \\
$\tau_{\mathrm{W}}$ & $0.02 \mathrm{~N} / \mathrm{m}^{2}$ & $0.0 \mathrm{~N} / \mathrm{m}^{2}$ \\
\hline
\end{tabular}

Although some adjustments had to be made in the free parameters, small discrepancies were observed in the salinity profiles (Fig. 7-A) and the Skill parameter was near one (0.96). Theoretical salinity values minus the observational ones for the neap tidal cycle varies 0.58 psu at the surface, less than 0.05 psu along the halocline and 0.30 psu at the bottom. For the v-velocity profile a good correspondence (less than $0.008 \mathrm{~m} / \mathrm{s}$ ) between the theoretical results and the observations was found (Fig. 7-B), and the Skill=1.0 indicates a very good fit. Inspection of the experimental and theoretical vertical profiles for the spring tidal cycle (Fig. 8-AB) shows the model also gives a good agreement for the steady-state v-velocity component (Skill=0.98). However, although the salinity profiles have similar configuration, for this tidal regime the theoretical salinity values minus the observational ones varies from 0.07 psu and 0.13 psu on the surface and bottom, respectively, with higher deviation along the halocline: from 0.20 up to $0.40 \mathrm{psu}$, and the validation parameter is close to 0.97 . 
(A)

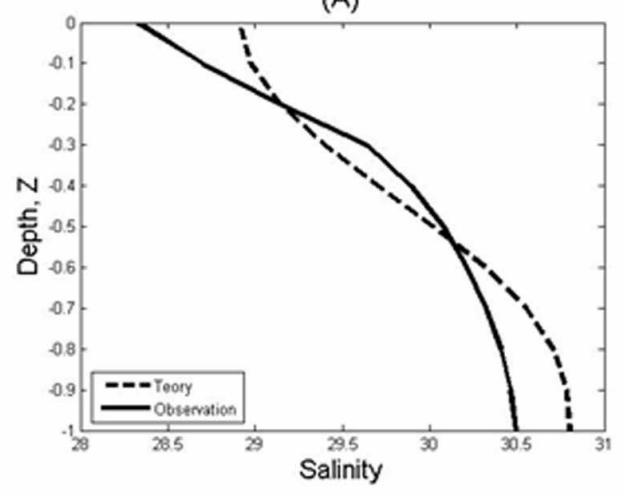

(B)

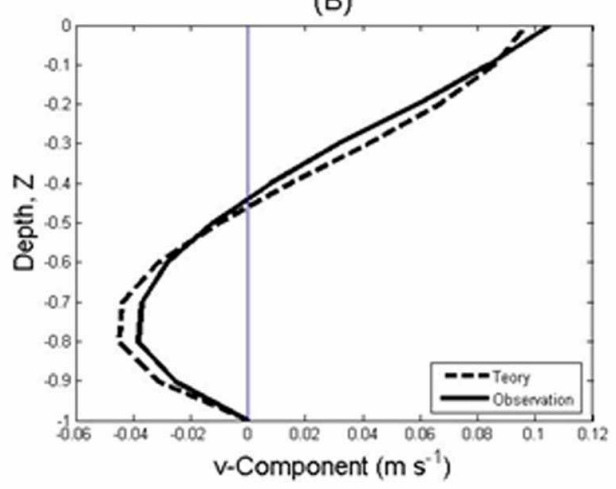

Fig. 7. Observational versus theoretical profiles for the neap-tidal cycle. Salinity (A) and v-velocity component (B). The validation Skill parameters are 0.96 and 1.00, respectively.

(A)

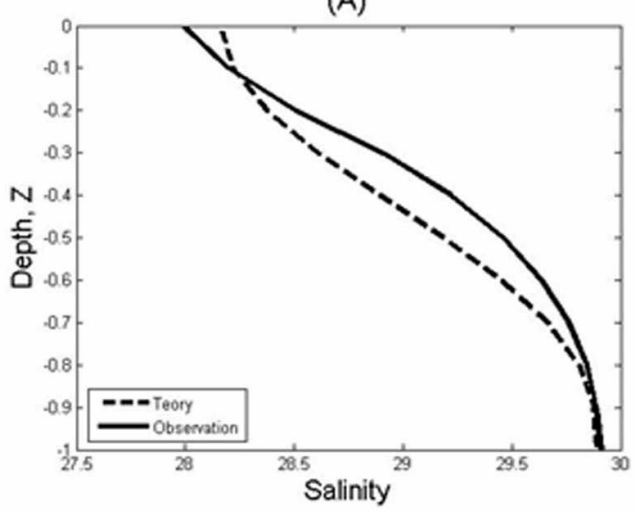

(B)

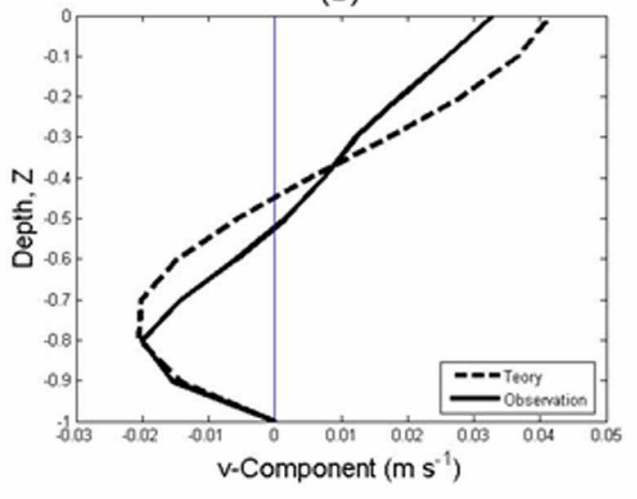

Fig. 8. Observational versus theoretical profiles for the spring-tidal cycle. Salinity (A) and v-velocity component

(B). The validation Skill parameters are 0.98 and 0.97 , respectively.

According to the parameters used in the simulations (Table 1), it is worth to mentioning that: i) it was assumed a weak and a negligible wind stress at the neap and spring tidal cycles, respectively, and ii) as indicated above, some adjustments were necessary in the free parameters $\left(\mathrm{N}_{\mathrm{z}}, \mathrm{K}_{\mathrm{z}}\right.$ and $\left.\mathrm{K}_{\mathrm{ho}}\right)$.

\section{Channel Classification and TIDAL STRAINING}

The images of the stratification $\left[\mathrm{p}_{\mathrm{e}}=\left(\mathrm{S}_{\mathrm{f}^{-}}\right.\right.$ $\left.\left.\mathrm{S}_{\mathrm{s}}\right) / \mathrm{S}_{\mathrm{o}}\right]$ and circulation $\left[\mathrm{p}_{\mathrm{c}}=\left(\mathrm{v}_{\mathrm{s}} / \mathrm{v}_{\mathrm{a}}\right)\right]$ parameters of the Hansen \& Rattray's classification diagram obtained from data of Figs. 7 and 8 for the neap $\left(\mathrm{p}_{\mathrm{e}}=0.073\right.$ and $\left.\mathrm{p}_{\mathrm{c}}=11.42\right)$ and spring $\left(\mathrm{p}_{\mathrm{e}}=0.066\right.$ and $\left.\mathrm{p}_{\mathrm{c}}=12.49\right)$ tidal experiments with $v=0.85$, classify the Piaçaguera Channel as type 2a (partially mixed and weakly stratified) for both neap-spring tidal conditions (Fig. 9). Hence, $85 \%$ and $15 \%$ of up-estuary salt transport are due to tidal diffusion and the baroclinic shear, respectively.

The Stratification-circulation diagram was also used to classify the channel using the results of the steady-state analytical simulations of the vertical profiles of salinity and the v-velocity component, respectively, and the results were very close (Fig. 9), with the $v$ parameter almost the same (0.92). This result is independent on the tidal fortnightly modulation and may allow the conclusion that the tidal energy reaching the channel was insensitive to fortnightly time scale tidal modulation. These results are very different when compared to the ones from the lower reaches of the estuarine Bertioga Channel (the NE entrance of the Santos estuary), which was strongly influenced by the fortnightly tidal modulation and its classification changed from type $2 b(v=0.7)$ to type $2 \mathrm{a} v=0.9$ ) during the transition from the neap to spring tidal cycles based on winter time observations by Miranda et al. (1998). 


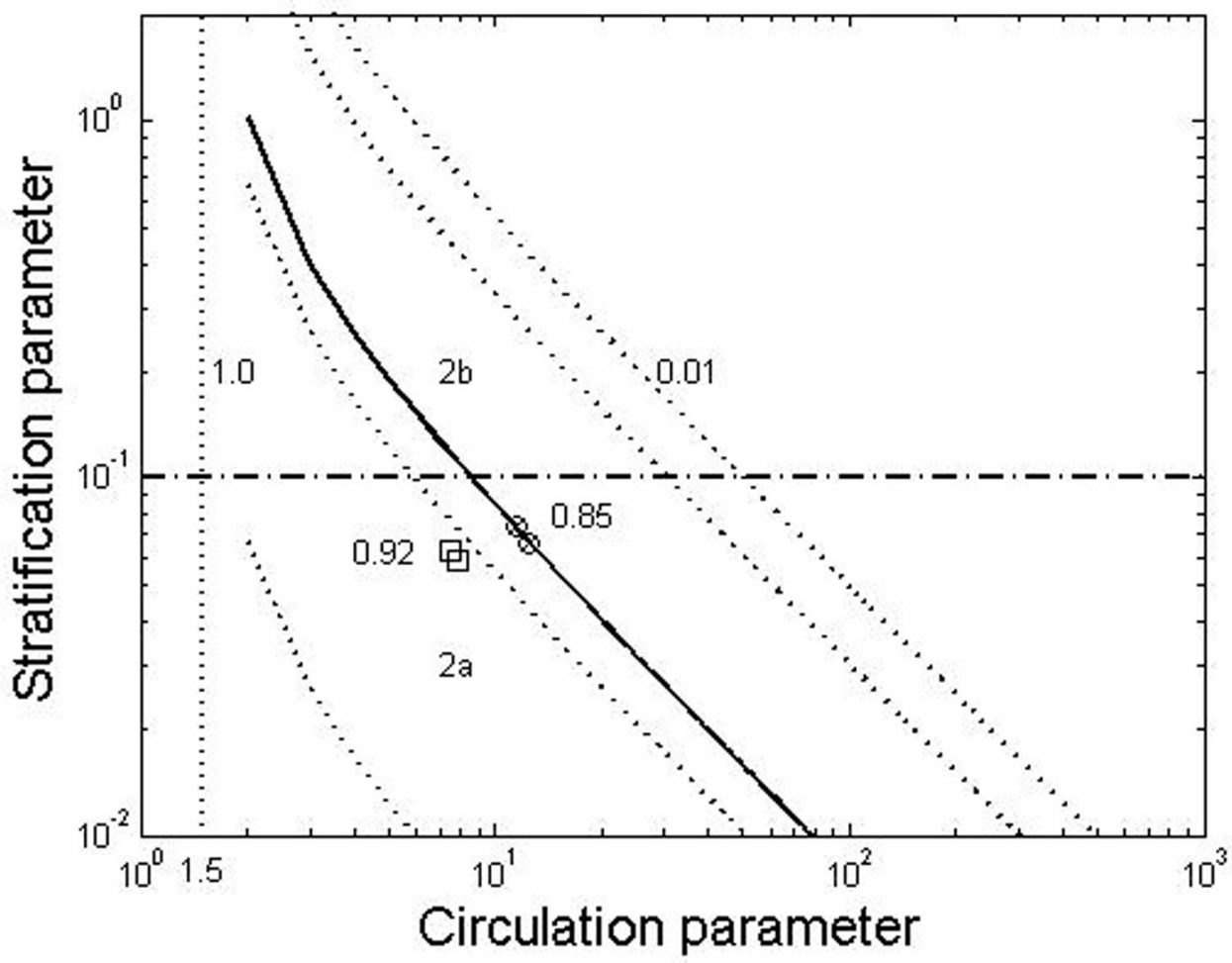

Fig. 9. Stratification-circulation diagram for neap and spring tide experiments. The channel is classified as Type $2 \mathrm{a}$ for both observational and theoretical profiles with $\mathrm{n}=0.85$ and $\mathrm{n}=0.92$, respectively.

The energy of the tidal straining process due to the fortnightly tidal modulation and its influence on water column stability was calculated in terms of the time rate of the potential energy anomaly $\phi$, according to Simpson et al. (1990). Such calculations used the steady-state results of the velocity profiles $\mathrm{v}=\mathrm{v}(\mathrm{Z})$ and its depth-mean value $\left(\mathrm{v}_{\mathrm{m}}\right)$. The N-S density gradient used in the equation (7) was the same of the analytical simulations $\left(1.2 \times 10^{-3} \mathrm{~kg} / \mathrm{m}^{4}\right)$. Our results indicate that there was a decrease in the time rate of the potential energy anomaly from $1.50 \times 10^{-3} \mathrm{~J} / \mathrm{m}^{3} . \mathrm{s}$ to $0.56 \times 10^{-3}$ $\mathrm{J} / \mathrm{m}^{3} . \mathrm{s}$, during the neap to spring tidal cycle transitional period, respectively. This decrease explain why the occurrence of the halocline break-down wasn't observed and the estuarine channel stratification remained partially mixed (Type 2a) in the spring tidal cycle.

Almost the same result may also be obtained using the correlation of $\mathrm{u}_{\mathrm{b}}$ (near bottom velocity) and the estuary depth (h) with the longitudinal density gradient used as a parameter, according to the Nunes et al. (1989). This correlation represents the balance of the potential energy due to the estuarine circulation and tidal stirring which is taken as the boundary between mixed and stratified regimes. By plotting the spring tide results (near bottom velocity at $\mathrm{Z}=0.9$ as $\mathrm{u}_{\mathrm{b}}=0.1 \mathrm{~m} / \mathrm{s}$ from Fig. 6) and $\mathrm{h}=11 \mathrm{~m}$ (Table 1) in the
Figure 3 of Nunes et al. (op. cit), the image of these values in the $u_{b}$ versus $h$ correlation lies well above the density gradient line $\left(1.2 \times 10^{-3} \mathrm{~kg} / \mathrm{m}^{4}\right)$ of the analytical simulations, which confirms that the production of turbulent kinetic energy was't enough to promote the vertical mixing of the water column in the spring tide.

\section{Conclusion}

During the fortnightly tidal modulation observation period the Piaçaguera channel remained as a partially mixed estuary and weakly stratified (type 2a) with almost de same mixing parameter calculated with experimental $(v=0.85)$ and theoretical data $v=0.92$ ). This independence on the tidal forcing may be justified by the decrease of the potential energy rate $\left(\frac{\partial \phi}{\partial t}\right)$ which ranged from $1.5 \times 10^{-3} \mathrm{~J} / \mathrm{m}^{3}$.s to $0.60 \times 10^{-3}$ $\mathrm{J} / \mathrm{m}^{3}$.s over the neap to spring tidal cycle, respectively.

Although the channel was type $2 \mathrm{a}$, the time variation of the layer Richardson number during the neap tide was much higher than the upper limit $\left(\mathrm{Ri}_{\mathrm{L}}>20\right)$ for which the turbulent mixing occurs in the halocline. However, in the spring tidal cycle were calculated values lower than the critical number $\left(\operatorname{Ri}_{\mathrm{L}}<20\right)$ and the bottom turbulence became effective. Due to the 
low value of the potential energy rate the vertical mixing process was inhibited in the spring tidal cycle.

Time variations of the longitudinal velocity component $(v)$ during the neap tidal conditions at the surface $(Z=0)$ were not well correlated with the underneath layers $(Z=-0.5$ and $Z=-0.9)$ variations due to a cold front passage generating winds with speeds up to $60 \mathrm{~km} / \mathrm{h}$. However, in the spring-tide a well correlation of the v-velocity component in the water column and the tidal oscillation was observed and they are almost in phase.

The classical momentum balance was appropriate to describe the essential steady-state dynamics of the estuarine channel which was mainly due to the fresh water discharge, the baroclinic gradient pressure and the dissipative frictional forces. During those experiments the baroclinic forcing towards the estuary-head reaches the northern part of the estuarine channel located at almost $17 \mathrm{~km}$ from its mouth. However, due to its low dynamics the Piaçaguera Channel was almost undisturbed by the fortnightly tidal modulation during this winter time observation period and may contribute to the sediment trapping in the inner estuary region.

The decrease in the salt transport components down and up-estuary due to the residual currents and the baroclinic forcing in the transitional period form the neap and spring tidal conditions indicates the tendency towards a balance in the spring tide.

\section{ACKNOWLEDGEMENTS}

We are grateful to the Conselho Nacional de Desenvolvimento Científico e Tecnológico (CNPq) for the Research Productivity Fellowship (Proc.302069/2004-6) and Ph.D. and M.Sc. fellowships concession to the authors and the Fundação de Estudos e Pesquisa Aquáticas (FUNDESPA). The collaboration of the graduate students of the Department of Oceanography, Chemistry and Geology of the University of São Paulo for their assistance with the field work is also very much appreciated, and to José Roberto Bairão Leite for processing the spectral tidal analysis. Minor editing was made by Patricia Leite de Miranda. We also thank an anonymous reviewer whose comments helped the article improvement

\section{REFERENCES}

ANDUTTA, F. P; MIRANDA, L. B.; CASTRO, B. M.; FONTES, R. F. C. Numerical simulation of the hydrodynamic in the Curimataú Estuary, RN Brazil.In: SIMPÓSIO BRASILEIRO DE OCEANOGRAFIA, 3. Oceanography and Global Changes, São Paulo, 2006. p. 545-558.
BÉRGAMO, A. L.; MIRANDA, L. B. DE; CORRÊA, M. A. Estuário: Programas para processamento e análise de dados hidrográficos e correntográficos. Rel. Téc. Instituto Oceanográfico, São Paulo , n. 49, p. 1-16, 2002.

BERNARDES, M. E. C.; MIRANDA, L. B. Circulação estacionária e estratificação de Sal em canais estuarinos: Simulação com modelos analíticos. Rev. bras. Oceanogr, v. 49, n. 1/2, p. 115-132, 2001.

BOWDEN, K. F. Mixing Processes in Estuaries. In: KJERFVE, B., (Ed.). Estuarine Transport Processes, Belle W. Columbia, N.C.: Baruch Library In Marine Science, University of South Carolina Press, 1978. p. 1116 (n. 7).

CETESB. Estudo da Circulação das Águas no Estuário de Santos. São Paulo: CETESB, 1977. 69 p. (Relatório Técnico).

CETESB. Metais pesados na Baía de Santos e Estuários de Santos e São Vicente. São Paulo: CETESB, 1981. 231 p. (Relatório Técnico).

CETESB. Contaminação do Sistema Estuário de Santos/São Vicente (SP) - Brasil. São Paulo: CETESB, 2001. 81 p. + anexos e mapas. (Relatório Técnico).

CTH. Baía de Santos. Levantamento de correntes na barra do porto para a Companhia Docas de Santos. São Paulo: USP-Escola Politécnica, Laboratório de HidráulicaDAEE, 1959. 12 p. +mapas.

CTH. Estuário Santista. Pesquisas sobre assoreamento verificado na faixa portuária para a Companhia Docas de Santos. São Paulo: USP-Escola Politécnica, Laboratório de Hidráulica-DAEE. 1966. v.1, 112 p.

DINIZ, G. L.; MEYER, J. F. C. A. Estudo e modelagem matemática da dispersão de poluentes em sistemas estuarinos. Biomatemática, v. 14, p. 103-118, 2004.

DYER, K. R.; A. L. NEW, Intermittency in estuarine mixing. In: WOLFE, D. A. (Ed.). Estuarine Variability. Orlando, Fla.: Academic Press, 1986. p. 321-339.

FIGUEIRA, R. C.; TESSLER, M. G.; MAHIQUES, M. M. DE; FUKUMOTO, M. M.; CAZZOLI, S.; GOYA, Y. Sedimentação recente e níveis de metais pesados em testemunhos do Estuário Santista, SP - Brasil. CONGRESSO BRASILEIRO DE PESQUISAS AMBIENTAIS E DA SAÚDE, CBPAS, 4. Santos, SP, 2004. Anais ... p. 73-76. (CD Rom).

FISCHER, H. B. Mixing and dispersion in Estuaries. Ann. Rev. Fluid Mech., v. 8, p. 107-133, 1976.

FRANCO, A. S. MARÉS: Programa para Previsão e Análise. In: São Paulo: Manual, BSP, 2000. 36 p.

FÚLFARO, V. J.; PONÇANO, W. L. Sedimentação atual do estuário e Baía de Santos: um modelo geológico aplicado a projetos de expansão da zona portuária. In: CONGRESSO BRASILEIRO DE GEOLOGIA E ENGENHARIA, 1, 1976. Rio de Janeiro. Anais... Rio de Janeiro: ABGE, v. 2, p. 67-90, 1976.

FÚLFARO, V. J.; REQUEJO, C. S.; LANDIM, P. M. B.; FÚLFARO, R. Distribuição de elementos metálicos nos sedimentos da baía de Santos. In: SIMPÓSIO REGIONAL DE GEOLOGIA, SBG, 4. São Paulo, 1983. p. $275-289$.

GIANESELLA, S. M. F.; SALDANHA-CORRÊA, F. M. P.; TEIXEIRA, C. Tidal effects on nutrients and phytoplankton distribution in the Bertioga Channel, São Paulo, Brazil. Aquat. Ecosys. Health Manag, v. 3, p. 533-544, 2000. 
HAMILTON, A .D.; WILSON, R. E. Nontidal circulation and mixing processes in the lower Potomac Estuary. Estuaries, v. 3, n. 1, p.11-19, 1980.

HANSEN, D. V.; RATTRAY, M., JR. Gravitational circulation in straits and estuaries. J. mar. Res., v. 23, n. 1, p. 102-122, 1965.

HANSEN, D. V.; RATTRAY M., JR. New dimensions in estuary classification. Liminol. Oceanogr., v. 11, n. p .319-325, 1966.

HARARI, J.; CAMARGO, R. Modelagem numérica da região costeira de Santos (SP): Circulação de Maré. Rev. bras. Oceanogr., S Paulo, v. 46, n. 2, p. 135-156, 1998.

HARARI, J.; CAMARGO; R.; MIRANDA, L. B. DE. Modelagem numérica hidrodinâmica tridimensional da região costeira e estuarina de São Vicente e Santos (SP). Pesquisa Naval, RJ, Suplemento, p. 79-97, 2001.

HARARI, J; MIRANDA, L. B.; BÉRGAMO, A. L.; CORRÊA, M. A. Hidrografia, correntometria e modelagem numérica em apoio a obras de engenharia costeira no canal de Piaçaguera (Santos-SP). In: CONGRESSO BRASILEIRO DE PESQUISAS AMBIENTAIS E DA SAÚDE, CBPAS, 2002, Santos, SP. p. 1-6. ( CD Rom).

MIRANDA, L. B. DE. ; CASTRO, B. M.; KJERFVE, B. Circulation and mixing in the Bertioga channel (SP, Brazil) due to tidal forcing. Estuaries, v. 21, n. 2, p. 204214, 1998.

MIRANDA, L. B. DE; CASTRO, B. M.; KJERFVE, B. Princípios de Oceanografia Física de Estuários. S. Paulo: EDUSP, 2002. 424 p. (Acadêmica 42).

MOSER, G. A. O.; GIANESELLA, S. M. F.; BARRERAALBA, J. J.; BÉRGAMO, A. L.; SALDANHACORRÊA, F. M. P.; MIRANDA, L. B. DE; HARARI. J. Instantaneous transport of salt, nutrients, suspended matter and chlorophyll-a in the tropical estuarine system of Santos. Braz. J. Oceanogr., v. 53, p. 115-127, 2005.

NUNES, R. A.; LENNON, G. W.; SAMARASINGHE, J. R. $\mathrm{S}$. The negative role of turbulence in Estuarine mass Transport. Estuar. coast. Shelf Sci., v. 28, p. 361-377, 1989.
OFFICER, C. B. Physical Oceanography of Estuaries and Associated Coastal Waters. New York: John Wiley \& Sons, $1976.465 \mathrm{p}$.

OFFICER, C. B. Longitudinal Circulation and Mixing Relations in Estuaries. Estuaries, Geophysics, and the Environment. Studies in Geophysics. The National Research Council, 1977. p. 13-21.

PAWLOWICZ, R.; BEARDSLEY, B.; LENTZ, S. Classical tidal harmonic analysis including error estimates in MATLAB using T_TIDE. Computers, Geosciences, v. 28, p. 929-937, 2002 .

PRANDLE, D. On salinity regimes and the vertical structure of residual flows in narrow tidal estuaries. Estuar. coast. Shelf Sci., v. 20, p. 615-635, 1985.

PRANDLE, D. Saline intrusion in partially mixed estuaries. Estuar. coast. Shelf Sci., v. 59, p. 385-397, 2004.

SIMPSON, J. H.; VENNELL, R.; SOUZA, A. J. The salt fluxes in a tidally-energetic estuary. Estuar.coast. Shelf Sci., v. v. 52, p. 131-142, 2001.

SIMPSON, J. H.; BROWN, J.; MATTEWS, J.; ALLEN, G. Tidal straining, density currents, and stirring in the control of Eeuarine stratification. Estuaries, v. 13, n. 2, p.125-132, 1990.

WARNER, J. C.; GEYER, W. R.; LERCZAK, J. A. Numerical modeling of an estuary: A comprehensive skill assessment. J. Geophys. Res., v. 110(CO5001), p. 1-13. 2005.

WILMOTT, C. J. On the validation models. Phys. Geogr., n. 2, p. 184-194, 1981

(Manuscript received 16 June 2010; revised 23 October 2011; accepted 20 November 2011) 